Marquette University

e-Publications@Marquette

$3-1-2002$

\title{
Credit Rationing in the U.S. Mortgage Market: Evidence from Variation in FHA Market Shares
}

Brent W. Ambrose

University of Kentucky

Anthony Pennington-Cross

Marquette University, anthony.pennington-cross@marquette.edu

Anthony M. Yezer

George Washington University

Accepted version. Journal of Urban Economics, Vol. 51, No. 2 (March 2002): 272-294. DOI. (C) 2002 Elsevier. Used with permission.

NOTICE: this is the author's version of a work that was accepted for publication in Journal of Urban Economics. Changes resulting from the publishing process, such as peer review, editing, corrections, structural formatting, and other quality control mechanisms may not be reflected in this document. Changes may have been made to this work since it was submitted for publication. A definitive version was subsequently published in Journal of Urban Economics, VOL 51, ISSUE 2, March 2002, DOI.

Anthony Pennington-Cross was affiliated with the Office of Federal Housing Enterprise Oversight at the time of publication. 


\title{
Credit Rationing in the U.S. Mortgage Market: Evidence from Variation in FHA Market Shares ${ }^{1}$
}

\author{
Brent W. Ambrose \\ Center for Real Estate Studies, Gatton College of Business and Economics, \\ University of Kentucky, Lexington, Kentucky 40506-0034 \\ E-mail: ambrose@uky.edu \\ Anthony Pennington-Cross \\ Office of Federal Housing Enterprise Oversight, 1700 G St. NW, \\ Washington, DC 20552 \\ E-mail: APennington-Cross@ofheo.gov \\ Anthony M. Yezer \\ Department of Economics, George Washington University, \\ Washington, DC, 20052-0110 \\ E-mail: yezer@gwu.edu
}

This paper examines the nature of mortgage credit rationing across geographic markets and time. Particular attention is paid to the response of conventional mortgage supply to higher risk conditions associated with regional recessions. We develop a series of four indirect tests based on the spatial variation of the FHA share of mortgages, both endorsements and applications, as well as FHA and conventional rejection rates. Results of these four tests indicate that conventional mortgage underwriting criteria do not become more flexible and may even become more demanding when local economic conditions deteriorate. This result indicates the use of non-price credit rationing in the mortgage market and suggests a special role for FHA-insured mortgages as a mechanism for maintaining mortgage credit supply in declining housing markets.

\section{INTRODUCTION}

\footnotetext{
${ }^{1}$ We thank Jan Brueckner, Charles Capone, Amy Crews-Cuts, Peter Linneman, Todd Sinai, the anonymous referees, and the seminar participants at the Fannie Mae Foundation and UC Berkeley for their helpful comments and suggestions. An earlier version of this paper was presented at the 1998 AREUEA Annual meeting. Partial financial support was provided by the Department of Housing and Urban Development Office of Policy Development and Research under contract DU100C000018441. Brent Ambrose acknowledges the support received by the Samuel Zell and Robert Lurie Real Estate Center Research Sponsors Program at the University of Pennsylvania.
} 
In this paper, we test the nature and existence of non-price credit rationing in single-family residential mortgage markets in the United States by exploiting the institutional fact that conventional lenders, including private mortgage insurers (PMIs), are free to vary conventional underwriting criteria across spatial markets (but not within markets), whereas the Federal Housing Administration (FHA) imposes spatially uniform underwriting standards for all FHAinsured mortgages. ${ }^{2}$ Thus, in originating FHA and conventional mortgages, lenders in spatially defined mortgage markets across the United States are free to alter conventional mortgage underwriting criteria to reflect changing economic conditions while also offering FHA-insured mortgages with uniform underwriting criteria.

In areas experiencing an economic downturn, the risk of mortgage lending increases and the percentage of low-risk mortgage applicants falls. The resulting decline in demand for lower-risk conventional mortgages means that conventional lenders must cut prices if they are to maintain their market share in declining areas. Cutting price explicitly, in the form of lower mortgage rates or insurance fees, is inconsistent with observed price invariance over space. ${ }^{3}$ Thus, if conventional lenders attempt to maintain their market share in declining (higher risk) areas, they must do so by relaxing underwriting criteria. Alternatively, conventional lenders may maintain underwriting standards and allow their market share to fall as fewer applicants are able to qualify. We develop a number of indirect tests for non-price rationing by conventional lenders in response to local differences in economic conditions, based on the implications of that behavior for the relative shares of FHA and conventional mortgage activity.

Recently expanded Home Mortgage Disclosure Act (HMDA) reporting requirements covering virtually all mortgage banking firms allow for the observation of spatial variation in patterns of applications, endorsements, and rejections for both conventional and FHA mortgages.

Supplementing HMDA data with FHA internal records allows us to characterize the risk structure of FHA endorsements. Thus, for the first time, we can test a number of hypotheses concerning

\footnotetext{
${ }^{2}$ The GAO [18] notes that, under FHA program guidelines, FHA mortgage underwriting criteria and premium structure do not deviate across geographic locations. Although conventional lenders and PMI maintain spatially uniform pricing structures (Duca and Rosenthal [8]), they may vary underwriting criteria spatially. The FHA may vary underwriting guidelines to a limited extent in response to Presidential decrees following natural disasters; however, these variations are highly localized.

${ }^{3}$ For a recent theoretical treatment that predicts a mortgage market equilibrium characterized by non-price rationing, see Brueckner [2]. Furthermore, Duca and Rosenthal [8] note that Fair Lending Laws make it difficult for lenders to differentially price applicants based on applicant risk
} 
the nature of credit rationing by conventional mortgage lenders. We also find that substantial variation in the FHA's share of mortgage activity persists even after adjusting for the effects of the FHA loan limits and for the institutional composition of local mortgage markets.

We are not aware of any previous similar study of FHA market shares that considers the full range of applications, endorsements, and rejections analyzed here. However, there is a literature on FHA mortgage choice that relies on survey microdata from the American Housing Survey (AHS), the Survey of Consumer Finances, or similar surveys. ${ }^{4}$ Because these surveys examine relatively few new mortgages each year in each Metropolitan Statistical Area (MSA) studies using them cannot evaluate spatial variation in credit rationing behavior between FHA and conventional lenders. Indeed, these studies implicitly assume that underwriting criteria do not vary spatially.

We devise a series of tests designed to detect the nature of credit rationing for conventional mortgages in spatially distinct mortgage markets, specifically MSAs. In contrast to other studies, we take advantage of the unique position of the FHA as a specialized high-cost, high-risk, spatially invariant insurance program in constructing our tests. Appropriate tests for the nature of credit rationing in mortgage markets require examination of the way in which a number of market indicators, in addition to FHA market share, vary with risk. Accordingly, we first present a model of market responses to shifting MSA credit risk conditions and then perform a number of tests based on this model. The empirical results are consistent with the findings of Duca and Rosenthal [7] and indicate that FHA market shares increase as economic uncertainty increases. Taken together, these tests provide a substantial indication of the role of spatial risk differentials and credit rationing by conventional lenders in mortgage lending.

\section{A SIMPLE MODEL OF MORTGAGE CREDIT RATIONING}

Following Hendershott et al. [12], we assume homebuyers recognize that the cost of FHA mortgage insurance relative to the cost of private mortgage insurance (PMI) varies based on loan-to-value and other characteristics, with conventional PMI being more (less) expensive for

\footnotetext{
${ }^{4}$ For example, a number of researchers, including Linneman and Wachter [13], Gabriel and Rosenthal [10], Goodman and Nichols [11], and Hendershott et al. [12] have used microdata on individual households to study the choice between conventional and government-insured mortgages.
} 
borrowers seeking high (low) loan-to-value mortgages. ${ }^{5}$ Accordingly, applicants trade off constraints on house value and higher required down payments for the lower cost of conventional mortgages. These arguments are part of an established theoretical literature backed by empirical testing using microdata on individual households. ${ }^{6}$ Goodman and Nichols [11] introduce the term "FHA wedge" to describe the group of applicants whose loan-to-value ratio is between $95 \%$ and $100 \%$ and/or have a front end ratio between $28 \%$ and $33 \%$. Such applicants are very likely to be rejected for conventional mortgages but are likely to qualify for FHA-insured mortgages.

Following an approach used by Ferguson and Peters [9], we assume that all relevant information concerning the applicant's ability to qualify for a mortgage, including credit history, collateral quality, and loan terms, can be quantified by a "mortgage credit score." Credit risk, $\Phi$, is a monotonically increasing function that captures the borrower's probability of default. ${ }^{7}$ Each lender sets uniform underwriting standards such that all applicants with a credit risk above a minimum acceptable risk level, $\Phi^{*}$, are rejected, whereas all applicants with a credit risk below $\Phi^{*}$ are accepted. The marginal probability density function of an applicant's risk is $r(\Phi)$, and $R(\Phi)$ is the cumulative density function.

The probability that a borrower applies for a FHA mortgage is a function of both the borrower's credit risk $(\Phi)$ and the lenders' conventional underwriting standards $\left(\Phi^{\mathrm{C}}\right)$. Households with $\Phi$ significantly below $\Phi^{\mathrm{C}}$ are very likely to choose lower-cost conventional mortgages. However, some households, fearing possible rejection for conventional loans, apply for FHA insurance, although their credit risk is below the conventional standard $\left(\Phi<\Phi^{\mathrm{C}}\right)$, whereas other households, less concerned with possible rejection than with insurance cost, apply for conventional loans with $\Phi>\Phi^{\mathrm{C}}$. Pennington-Cross and Nichols [15] demonstrate that although the cumulative distribution functions (CDF) of credit scores reported by the Fair, Isaac and Company (FICO) for FHA and conventional borrowers have considerable overlap, the

\footnotetext{
${ }^{5}$ For borrowers with high loan-to-value mortgages (greater than 95\%), FHA insurance premiums are lower than PMI premiums. For borrowers at the 95\% LTV cutoff, the relative cost advantage or disadvantage of FHA over PMI depends upon a number of factors, including whether the applicant qualifies for the first-time home buyer credit or the central city discount credit rationing

${ }^{6}$ See Linneman and Wachter [13], Gabriel and Rosenthal [10], Zorn [20], Sa-Aadu and Sirmans [16], Goodman and Nichols [11], and Hendershott et al. [12].

${ }^{7}$ We normalize $\Phi$ such that $\Phi \in(0,1)$.
} 
probability of applying to FHA decreases monotonically with increasing FICO scores. Thus, if we assume that $\Phi$ can be interpreted as the inverse of the credit score, then we can define $\alpha\left(\Phi ; \Phi^{\mathrm{C}}\right)$ as the share of FHA applicants at a given risk level indexed by $\Phi$, given current conventional lending standards $\left(\Phi^{\mathrm{C}}\right)$ Thus, $\alpha\left(\Phi ; \Phi^{\mathrm{C}}\right)$ is an increasing function of $\Phi$. Following Pennington-Cross and Nichols [15], we note that because mortgage insurance charges for lower-risk conventional mortgages are generally lower than FHA insurance rates, $\alpha\left(\Phi ; \Phi^{\mathrm{C}}\right)$ is approximately 0 when $\Phi \ll \Phi^{\mathrm{C}}$ and increases monotonically until it equals unity at some value $\Phi^{\prime}$, where $\Phi^{\mathrm{C}}<\Phi^{\prime}<\Phi^{\mathrm{F}}$ and $\Phi^{\mathrm{F}}$ is the upper limit of credit risk acceptable to the FHA.

We consider the case of a spatially defined, local market where lenders offer both conventional and government-insured (FHA) mortgage products. ${ }^{8}$ Figure 1 illustrates the distribution of applicant outcomes in this market. The marginal density function of credit risk $r(\Phi)$ is drawn, reflecting the empirical fact noted by Pennington-Cross and Nichols [15] that the peak of the marginal density function falls at a level of credit risk less than the maximum credit risk acceptable given conventional underwriting standards, indicated by $\Phi^{\mathrm{C}}$.

We note that the fraction of all applicants who apply for an FHA mortgage, $A\left(\Phi^{\mathrm{C}}\right)$, given that the risk distribution of the population is characterized by

$R(\Phi)$, is given by

$$
A\left(\Phi^{\mathrm{C}}\right)=\int_{0}^{1} r(\Phi) \alpha\left(\Phi ; \Phi^{\mathrm{C}}\right) d \Phi
$$

In Fig. 1, the value of $A(\cdot)$ is given by $S+T+V$. The fraction of all mortgage applications that result in an endorsed FHA mortgage, $E\left(\Phi^{\mathrm{C}} ; \Phi^{\mathrm{F}}\right)$ is

$$
E\left(\Phi^{\mathrm{C}} ; \Phi^{\mathrm{F}}\right)=\int_{0}^{\Phi^{\mathrm{F}}} r(\Phi) \alpha\left(\Phi ; \Phi^{\mathrm{C}}\right) d \Phi
$$

The value of $E(\cdot)$ is given by $S+T$ in Fig. 1. The fraction of all mortgage applications resulting in denial of FHA mortgage insurance, $D\left(\Phi^{\mathrm{C}} ; \Phi^{\mathrm{F}}\right)$, is

\footnotetext{
${ }^{8}$ The two loan products may either be offered by different lenders or, more likely, by a single lender. Applicants select the type of product that they prefer. Institutionally, it is often true that loan underwriting is segmented by loan product. 


$$
D\left(\Phi^{\mathrm{C}} ; \Phi^{\mathrm{F}}\right)=\int_{\Phi^{\mathrm{F}}}^{1} r(\Phi) \alpha\left(\Phi ; \Phi^{\mathrm{C}}\right) d \Phi
$$

The region $V$ in Fig. 1 represents $D(\cdot)$. Similar relations can be developed for shares of applications, endorsements, and denials for conventional lenders, recognizing that their share of applications for individuals with credit risk $\Phi$ is simply $\left[1-\alpha\left(\Phi ; \Phi^{\mathrm{C}}\right)\right]$.

All applicants with credit risk $\Phi$ greater than $\Phi^{\mathrm{C}}$ are rejected for conventional mortgages, either by the lender or by the mortgage insurer. We assume that the lender can vary conventional underwriting standards, $\Phi^{\mathrm{C}}$, whereas the FHA has fixed underwriting standards, $\Phi^{\mathrm{F}}$. Thus, we can test whether various market shares change differentially, depending on the flexibility of conventional underwriting standards. Although we are not able to observe the actual credit risk $(r(\Phi))$ distribution, we know that most applicants succeed in qualifying for conventional loans and have an incentive to provide credit enhancements, principally an additional down payment, to qualify for lower-cost PMI. ${ }^{9}$ Other applicants are unable to provide these enhancements, and they fall into the shaded region $T$ in Fig. 1 between $\Phi^{\mathrm{C}}$ and $\Phi^{\mathrm{F}}$, known as the "FHA wedge." This is the portion of the distribution of applications that would be rejected by conventional lenders and accepted by FHA. ${ }^{10}$

We are interested in the effects of a shift in credit risk due to changing economic conditions. A downturn in the local economy causes the probability density function of applicant risk $r(\Phi)$ to shift to $r^{\prime}(\Phi)$. Thus, $r^{\prime}(\Phi)$ reflects an increase in risk in that $R^{\prime}(\Phi)<R(\Phi) \forall \Phi$. We follow Ferguson and Peters [9] in defining an increase in risk as a shift in the risk distribution of mortgage applicants such that $R^{\prime}(\Phi)$ first order stochastically dominates (FOSD) $R(\Phi)$.

We develop testable hypotheses about the differential effects of alternative responses of conventional lenders to increases in credit risk that result when $r(\Phi)$ shifts to $r^{\prime}(\Phi)$, where $r^{\prime}(\Phi)$ FOSD $r(\Phi)$. Specifically, we form a series of testable hypotheses that allow us to determine the effects of changes in the underwriting criteria of conventional lenders and PMI underwriters in response to increases in local economic risk on (1) the FHA share of

\footnotetext{
${ }^{9}$ In fact, many borrowers put just enough down to qualify for conventional financing, thus producing a hump at the conventional lending limit.

${ }^{10}$ In essence, these are the applications for which FHA has no competition-the modest share of the FHA wedge applying for conventional credit and being rejected possibly reflects imperfect information on the part of applicants.
} 
applications, (2) the FHA share of originations, (3) the FHA rejection rate, and (4) the conventional rejection rate. ${ }^{11}$ Each of these four tests can be rigorously derived based on an analysis of Eqs. (1)-(3). ${ }^{12}$

First, consider the case where conventional lenders do not alter underwriting standards in response to an increase in local economic risk. Figure 2 shows this market equilibrium in which $\Phi^{\mathrm{C}}$ is constant, i.e., conventional underwriting criteria are inflexible, or lenders engage in complete non-price rationing. When $\Phi^{\mathrm{C}}$ remains constant and $r(\Phi)$ shifts to $r^{\prime}(\Phi)$, where $r^{\prime}(\Phi)$ FOSD $r(\Phi)$, then $r(\Phi) \alpha\left(\Phi, \Phi^{\mathrm{C}}\right)$ increases monotonically. It follows that the FHA share of applicants, $A\left(\Phi^{\mathrm{C}}\right)$, and the FHA share of originations, $E\left(\Phi^{\mathrm{C}}, \Phi^{\mathrm{F}}\right)$, increase accordingly. Because the FHA underwriting criteria are constant, the effect on the FHA rejection rate is ambiguous, because both the share of FHA applicants and the number of FHA rejections increase. This leads to a counterintuitive result-that as the risk distribution increases, the FHA rejection rate does not necessarily increase as well. However, because conventional underwriting criteria remain constant in response to an increase in local risk, conventional endorsements will be lower while the FHA wedge increases. Thus, our theory predicts that the conventional rejection rate will rise. ${ }^{13}$

Now consider the case where conventional lenders relax their underwriting standards in response to an increase in local economic risk, as illustrated in Figure 3. This hypothesis is consistent with the Government-Sponsored Enterprises' (Fannie Mae and Freddie Mac) charters to maintain mortgage credit in declining markets. Furthermore, conventional lenders have a high ratio of fixed to variable cost, suggesting that they would lower prices (i.e., relax underwriting standards) to maintain market share in the face of falling demand. It is important to recognize that increasing credit risk appears to the conventional lender as a decline in demand because the number of qualified mortgage applicants falls. The impact on the FHA's share of

\footnotetext{
${ }^{11}$ Because part of the mission of FHA is the maintenance of mortgage supply in declining markets, $\Phi^{\mathrm{F}}$ should not change because of changes in local economic risks. Weicher [19] notes that, as a result of the dramatic increase in mortgage defaults during the Great Depression, Congress created the FHA to help restore stability to the housing finance system. Subsequently this role has been interpreted as requiring that the FHA maintain the supply of mortgage credit in geographically concentrated recessions by providing mortgage insurance when local economic conditions deteriorate, and particularly by ignoring risks associated with falling home prices.

${ }^{12}$ A formal derivation is available from the authors upon request.

${ }^{13}$ This result rests upon the assumption that the peak of the applicant risk distribution is less than $\Phi^{\mathrm{C}}$, which is consistent with the empirical findings of Pennington-Cross and Nichols [15].
} 
applications is ambiguous, because both $r(\Phi) \alpha\left(\Phi ; \Phi^{\mathrm{C}}\right)$ and $\Phi^{\mathrm{C}}$ are shifting. However, the increase in $\Phi^{\mathrm{C}}$ will reduce the FHA share of originations. The reasoning is as follows: if conventional lenders increase $\Phi^{\mathrm{C}}$ to maintain their market share, and if total applications are unchanged, and if the FOSD condition ensures that the number of FHA rejections increases (because $\Phi^{\mathrm{F}}$ does not change), then FHA originations must fall by the same amount by which the number of FHA rejections rises. Similarly, if the number of FHA rejections increases and FHA originations fall, then the FHA rejection rate must rise. Finally, we note that the effect of increasing $\Phi^{\mathrm{C}}$ on the conventional rejection rate is ambiguous. Table 1 summarizes the predicted effects on applications, originations, and rejection rates by an increase in local economic risk under the two scenarios for conventional lender reaction to a decline in demand.

\section{EMPIRICAL TESTS FOR THE NATURE OF MORTGAGE CREDIT RATIONING}

Table 2 reports the geographic variation in the FHA share of FHA-eligible mortgages, i.e., those meeting the maximum mortgage limit. Market shares are calculated from information contained in the Home Mortgage Disclosure Act (HMDA) database, from which we identify FHA-eligible loans as either (1) FHA-insured originations and applications for owner-occupied home purchase loans, excluding refinancing, or (2) conventional (excluding Veterans Administration and Farmers Home Administration loans) originations and applications for owner-occupied home purchase loans, excluding refinancing, that meet the FHA loan limits. ${ }^{14}{ }^{15}$ The market shares are calculated for 307 MSAs, and population-weighted averages are computed for the respective HUD Regions during the 1995-1996 period for which extended HMDA coverage is available. Given that the FHA loan limit varies across MSAs, the loan amount needed for FHA eligibility is county specific. ${ }^{16}$ Standard deviations reflect MSA deviations in FHA share within

\footnotetext{
${ }^{14}$ The dataset contains all FHA-eligible conventional loans as identified by HMDA, including those originated by subprime lenders. However, because the analysis is confined to purchase mortgage loans (not refinance loans), the number of subprime loans in the dataset is extremely small (approximately less than 1\%).

${ }^{15}$ Because FHA loan limits vary within each year, we use the weighted average loan limit, where the weight is the number of months the limit is in force, as indicated by a HUD Mortgagee Letter or the Federal Register.

${ }^{16}$ The FHA defines loan limits by MSA and country, grouped into high and standard cost areas. All standard cost areas have the same loan limit, whereas all high-cost areas, whether a county or MSA, have a more lenient loan limit. For most high-cost areas, the loan limit is defined as $95 \%$ of the median house price, but substantial local office discretion is allowed in setting the 95\% loan limits. This 95\% rule holds until it is greater than $75 \%$ of the Federal Home Loan Mortgage Corporation (FHLMC) loan limit, at which point the FHA loan limit is reset to $75 \%$ of the FHLMC loan limit. All loans in the HMDA data set that have a county identifier are included as part of the FHA market if the loan is less than or equal to the loan limit set for the county.
} 
each HUD Region. Geographic divergences, other than the large Rocky Mountain share, are modest, as are differences over time. The differences by MSA within each state are more dramatic, sometimes exceeding a factor of $10 .{ }^{17}$ This is significant because many aspects of the institutional and regulatory environment governing mortgage markets are essentially uniform within a state. These very substantial differences in the FHA share of FHA-eligible mortgages remain to be explained.

To test the hypotheses outlined above, we calculate four alternative share variables: (1) FHA share of total FHA-eligible mortgage loans originating in MSA $i$ in year $t$, (2) FHA share of all applications for FHA-eligible mortgage loans originating in MSA $i$ in year $t$, (3) the FHA rejection rate, and (4) the conventional rejection rate for FHA-eligible loans. Based on the comparative static results from the previous section, we examine the nature of geographic variation in these market shares by estimating a series of reduced-form models that fit the generic form

$$
Y_{i t}=\beta_{0}+\beta_{1} C_{i t}+\beta_{2} P_{1}+\beta_{3} M_{1}+\beta_{4} L_{i t-1}+\beta_{5} H_{i}+\beta_{6} T+\varepsilon_{i t},
$$

where $Y_{i t}$ is a vector of various "share" variables (explained above) across $i=307$ MSAs and $t=$ 2 years (1995 and 1996), the $\beta_{j}$ 's are vectors of parameters to be estimated, $C_{i t}$ is a vector of variables reflecting cyclical economic conditions in the MSA economy, $P_{i}$ is a vector of relatively permanent indicators of MSA economic conditions, $M_{i t}$ is a vector of variables indicating characteristics of the minority population, $L_{i t-1}$ is a vector of lender share variables indicating the fraction of mortgage originations made by different types of institutions in the previous year, $H_{i}$ is a vector of HUD regional dummies, $T$ is a time dummy indicating observations from 1995, and $\varepsilon_{i t}$ is an identically and independently distributed random error term. Table 3 contains a listing of all variables used in the model along with descriptive statistics.

Because the market shares $\left(Y_{i t}\right)$ are proportions of a population, they should be treated as grouped observations. With grouped data, the unconditional variance is $Y_{i t}\left(1-Y_{i t}\right) / N_{i t}$, where $N_{i t}$ is the number of observed events in MSA $i$ in year $t$ used to calculate $Y_{i t}$. As a result, the efficiency of the estimator of $\beta$ is underestimated. Because the market shares are based on different numbers of observations in each MSA, the variance of the estimates differs by MSA

\footnotetext{
${ }^{17}$ Results are available upon request.
} 
depending on $N_{i t}$. To control for this difference in variances, we estimate Eq. (10) via maximum likelihood as a logistic probability model with unscaled weighting, where $N_{i t}$ is the weighting variable. This procedure often produces very small standard errors, leading to large $t$-statistics, suggesting statistical significance. We also report the marginal effects to infer economic impact.

\subsection{Cyclical Risk Factors}

To capture the shifts in the risk density function we include several variables designed to measure cyclical changes in economic risk associated with a particular MSA, including measures of housing, labor, and lending market conditions. Specifically, the local cyclical risk measures include the change in local house prices, the change in unemployment, and the percentage change in delinquent bank loans. Yearly changes $(\Delta H P)$ in house prices are estimated from the Freddie Mac MSA Repeat Sales Index. Empirical studies of credit risk have demonstrated a negative relation between house price appreciation and default loss (see Capozza et al. [4], Deng and Calhoun [6], and Ambrose and Capone [1]).

On average, local area house prices increased by $4.3 \%$ over the previous year. However, wide variation exists across the country, ranging from a $7.1 \%$ decline (Honolulu, $\mathrm{HI}$ ) to a $12.6 \%$ increase (Provo-Orem, UT) over the previous year. Cyclical changes in the labor market are measured by the yearly change in the local unemployment rate $(\Delta U)$, with increases in the unemployment rate indicating areas experiencing labor market distress. As with the housing market, borrower credit risk deteriorates in areas experiencing local recessions, and thus FHA market share should be higher in areas with increasing unemployment rates. Even during this period of generally robust economic conditions, many MSAs experienced a dramatic increase in unemployment rate.

To measure cyclical changes in the local creditworthiness of applicants, we include the percentage change in delinquency rate of bank loans in the previous year $(\triangle D E L)$ as reported by the American Bankers Association. ${ }^{18}$ The delinquency rate is reported by state and includes all consumer loans (e.g., credit cards and personal lines of credit). Thus, we anticipate that FHA market share should increase in areas experiencing higher levels of financial stress.

\footnotetext{
${ }^{18}$ Clauretie and Herzog [5] show that state foreclosure laws vary across states and do affect mortgage losses.
} 


\subsection{Permanent Risk Factors}

To measure the different shapes and positions of risk density functions across MSAs we include long-term measures of housing, employment, and demographic factors. For instance, MSAs with lower historical variation in the Freddie Mac repeat sales index, indicating more stable rates of house price change, are expected to be perceived as lower-risk areas. Because the cyclical risk factor $(\triangle H P)$ controls for the house price appreciation trend, we use its standard deviation, or $\sigma_{\Delta H P}$, to measure the volatility of the average growth rate of house prices. Greater volatility is associated with greater credit risk. A variety of institutional factors, including state laws governing bankruptcy and foreclosure, influence local credit risk. We incorporate a measure of these effects in the form of the average default rate for the previous 6 years for each state $\left(\overline{D E L_{t}}\right)$.

Based on previous research, we expect credit risk to be higher in areas with higher proportions of younger, lower-income households. We incorporate two income variables measuring these demographic characteristics associated with credit risk. One is the percentage of home buyers with income less than $\$ 20,000$ (INC < 20). As the percentage of lower-income home buyers increases, we expect a permanent increase in credit risk among mortgage applicants.

On average, $11 \%$ of home buyers fall into this category. However, the fraction of lower-income home buyers ranges from $0.2 \%$ (Nassau-Suffolk, NY) to over 30\% (Sumter, SC). The other is the percentage of loans where the ratio of the loan amount to borrower income is greater than three $(\mathrm{LTI}>3)$, which identifies areas with high house prices relative to income levels. ${ }^{19}$ On average, $5.7 \%$ of home buyers are classified as income constrained by this measure. Again, wide variation exists in this measure ranging from a minimum of $0.1 \%$ (Wichita Falls, TX) to a minimum of $51.5 \%$ (Honolulu, $\mathrm{HI}$ ). As the fraction of the FHA-eligible market with LTI $>3$ increases, we expect the risk probability density function to shift to the right.

\subsection{Minority Population}

\footnotetext{
${ }^{19}$ As a data quality control check, we follow Bunce and Scheessele [3] and exclude all loans with LTV greater than 6.
} 
Previous research has indicated that the FHA tends to differentially serve minority borrowers. ${ }^{20}$ Accordingly, we include variables reflecting the percentage of minority applicants and the extent of housing market segregation. Using HMDA, we calculate the percentage of loan applications under the FHA loan limit by black applicants (BLACK). The fraction of black applicants averages 6\% and ranges from 0 (Dubuque, IA; Eau Claire, WI; Billings, MT; Bismark, ND; Laredo, TX; Medford, OR; Rapid City, SD; Wausau, WI) to 42.5\% (Sumter, SC). We also incorporate a proxy for the level of local segregation $(B G I N I)$ to determine whether the FHA market share varies depending on the level of racial segregation. BGINI measures the spatial distribution of different groups across the local region and is derived from the Lorenz curve with values between 0.0 and 1.0, with 1.0 indicating maximum segregation (see Massey and Denton [14]). ${ }^{21}$ For our sample, we find that the average MSA has a $B G I N I$ coefficient of 0.3 , ranging from a minimum of 0.03 (Burlington, VT) to a maximum of 0.77 (Gary, IN).

\subsection{Lender Share Variables}

Finally, the variety of types of firms offering mortgage credit in the local market may have a direct effect on FHA market share of FHA-eligible mortgages. We capture the wide variety of lending institution types with a series of variables reflecting the government agencies collecting mortgage activity from lenders. For example, mortgage bankers, who report their mortgage activity to HUD, have historically had a closer association with FHA than with depository institutions, which report to a variety of regulatory agencies, including the Office of the Comptroller of the Currency (OCC), the Office of Thrift Supervision (OTS), the Board of Governors of the Federal Reserve, the National Credit Union Administration (NCUA), and the Federal Deposit Insurance Corporation (FDIC). Thus, we include the percentage of loans originated that were reported to HUD (mortgage bankers), the Office of the Comptroller of the Currency, the Office of Thrift Supervision, the Board of Governors of the Federal Reserve, the National Credit Union Administration, and the Federal Deposit Insurance Corporation, with the percentage of loans reported to HUD serving as the reference variable in the regression analysis. We note that substantial variation exists in the types of lenders originating mortgages in local markets. For example, the percentage of lenders reporting to HUD ranges from 3.7\%

\footnotetext{
${ }^{20}$ For example, see Shear and Yeser [17] for a discussion of the attractiveness of FHA to minority borrowers.

${ }^{21} B G I N /$ is calculated from the 1990 census block data.
} 
(Enid, OK) to $74.0 \%$ (Bakersfield, CA). In addition, banks and thrifts originate a large segment of loans, since lenders reporting to either the OCC or OTS originate $38.5 \%$ of all loans.

\section{RESULTS}

We summarize the hypotheses and empirical findings concerning the effect of an increase in local credit risk on FHA shares of applications, originations, and FHA and conventional rejection rates in Table 1. Estimation results are presented in Table 4, and marginal effects are presented in Table 5. Marginal effects are calculated by evaluating the first derivatives of the respective shares with respect to each independent variable evaluated at the overall means of the data. Thus, the marginal effects provide an indication of the effects that a one-unit change in the respective variables will have on the expected market shares. Because our primary interest is in variables reflecting changes in cyclical and permanent risk, we examine these effects in turn.

\subsection{Cyclical Risk}

Recall that increasing cyclical risk associated with a downturn in the local economy is measured by increases in unemployment $(\Delta U)$, increases in state level bank credit card delinquencies $(\triangle D E L)$, and declines in the percentage change in house prices in the current or previous year $\left(\Delta H P_{t}\right.$, or $\left.\Delta H P_{t-1}\right)$. We first examine the impact of an increase in cyclical risk on FHA and conventional rejection rates. Consistent with the view that the FHA does not alter its underwriting standards to reflect changes in local economic risk, we see that an increase in cyclical risk certainly does not raise FHA rejection rates and may even lower them. Of the four cyclical risk variables, only the coefficients capturing changes in house prices are significant, but they have opposite signs. In addition, the marginal effects for changes in house prices indicate that these factors essentially offset one another in the FHA rejection model. As discussed above, this apparently counterintuitive effect of local cyclical risk indicators on FHA rejection rates strongly suggests that lenders do not relax conventional underwriting standards in response to an increase in risk.

Turning to the conventional rejection rate model, we also find mixed results for the variables proxying for cyclical risk. Again, the variables for the changes in house prices have opposite signs, whereas the conventional rejection rate is positively related to increases in unemployment but negatively related to increases in the delinquency rate. Overall, the marginal 
effects indicate that factors associated with an increase in cyclical risk largely offset one another. These results are not consistent with the hypothesis that lenders maintain underwriting standards, which predicted a positive effect on conventional rejection rates in response to an increase in local risk.

Comparing the FHA and conventional rejection rate models, we find that the marginal effects on the estimated coefficients of variables capturing differences in cyclical risk in the FHA rejection rate model are smaller than the corresponding marginal effects for the conventional rejection rate model. For example, changes in the cyclical risk variables produce a shift between $0.16 \%$ $\left(\Delta H P_{t-1}\right)$ and $1.37 \%(\triangle D E L)$ in the conventional rejection rate, whereas similar changes in cyclical risk variables only result in an $0.08 \%$ to $0.11 \%$ change in the FHA rejection rate. This indicates that the FHA rejection rate is relatively less sensitive to changes in the local economic environment than is the conventional rejection rate.

Turning to the share equations, it appears that increasing cyclical risk is generally associated with an increase in the FHA share of originations and applications. For example, the marginal effects show that a $1 \%$ decline in the percentage change in the local house price index in the current and previous years results, respectively, in a $0.42 \%$ and $0.55 \%$ increase in the baseline FHA share of originations. In addition, a 1\% increase in the yearly percentage change in the unemployment rate and delinquency rate results, respectively, in a $0.33 \%$ and $0.59 \%$ increase in the baseline FHA share of originations. With the exception of the change in the unemployment rate, we find similar effects for the FHA share of applications. Thus, the marginal effects for cyclical risk factors indicate that FHA market shares of FHA-eligible originations and applications do vary substantially with economic conditions. Taken together, the results for cyclical risk factors for FHA applications and originations are consistent with the hypothesis that conventional lenders do not lower lending standards to maintain their market share in response to increases in cyclical risk.

\subsection{Permanent Risk}

Turning to variables reflecting changing permanent risk, we begin by observing that the most attractive indicator of permanent differences in credit risk is the standard deviation in the trend rate of appreciation in house prices $\left(\sigma_{\Delta H P}\right)$. The conventional rejection rate and FHA share of 
originations both vary directly with this indicator of risk, whereas the FHA rejection rate varies inversely with it. This is strongly consistent with the non-price rationing hypothesis.

Expanding our attention to the full set of permanent risk variables, we find that areas with higher historic average delinquency rates have a higher FHA market presence and higher conventional rejection rates. The marginal effects indicate that historic delinquency rates play a large role in altering FHA market shares and conventional rejection rates, confirming our prior expectations concerning the effect of area risk on market share. For example, in New York-New Jersey, an increase of one standard deviation in the historic delinquency rate translates into a 5-point increase in FHA originations and application market shares. Furthermore, we find that a higher permanent house price or equity risk is uniformly associated with higher FHA shares of both applications and originations, which is consistent with the hypothesis that lenders do not alter conventional underwriting behavior.

Turning to the FHA rejection rate model, we find economically weaker effects for our variables proxying for areas with higher permanent risk than in the conventional rejection rate model. As with the cyclical risk factors, this result is consistent with spatial uniformity of FHA underwriting standards across geographic markets.

Table 6 presents simulation results showing the effect of a significant increase in cyclical and permanent risk on FHA market share. Part A reports the baseline regional FHA market shares for HUD reporting financial institutions. As expected, there is a wide variation in FHA market shares across HUD regions. Part B simulates a short-term shock to the local economy by increasing $\triangle U$ and $\triangle D E L$ by one standard deviation (simulating an increase in unemployment and mortgage delinquency) and reducing $\Delta H P_{t}$ and reducing $\Delta H P_{t-1}$ by one standard deviation (simulating a decline in property values). The results indicate an overall increase in FHA market shares of originations and applications corresponding to a reduction in credit from conventional lenders. Consistent with predictions from the marginal effects, we find that shifts in cyclical risk factors appear to have a minimal impact on rejection rates. Part $C$ shows the effect of an increase in the permanent risk level for an area (permanent risk factors are increased by one standard deviation), holding all other factors constant. Again, FHA market shares for originations increase, but slightly less so than for a shock to cyclical risk factors. We also note that FHA rejection rates decline slightly, whereas conventional rejection rates increase. As summarized in Table 1, the empirical findings generally support the hypothesis that 
conventional lenders hold underwriting standards constant and fail to support the hypothesis that conventional lenders relax underwriting standards to maintain their market share during periods of increased risk.

\subsection{Minority Effects}

It is interesting to note that as the percentage of minority households that apply for mortgages in an area increases, the FHA market share of both originations and applications increases along with rejection rates. The effects for the fraction of mortgage loans with black applicants might have been anticipated based on the literature, suggesting that FHA insurance is differentially attractive to minorities. Specifically, the marginal effects show that a $1 \%$ increase in the fraction of black applicants in the previous year $\left(B L A C K_{t-1}\right)$ raises the baseline FHA market share of applications and originations by $0.54 \%$ and $0.45 \%$, respectively. This indicates that low-risk black applicants are more likely to choose FHA insurance, perhaps fearing rejection for conventional mortgages or steering by real estate brokers or loan officers, or believing that the FHA program offers an unbiased source of mortgage credit. The direct relation between FHA and conventional rejection rates and the fraction of black applicants may reflect the higher rejection rates experienced by minorities. However, the effects of our index of segregation of the MSA residential population (BGINI) fail to reinforce the black percentage effects. Specifically, MSAs with a more segregated population (higher BGINI) tend to have lower rejection rates for conventional loans and lower FHA market shares of applications and originations.

\subsection{Regional and Financial Institution Effects}

The main contribution of the estimated coefficients of the HUD regional dummy variables is to demonstrate that, even after taking into account variables reflecting cyclical and permanent components of credit risk, minority composition, and the composition of lenders active in the mortgage market, substantial geographic variation in FHA shares and rejection rates remains. In part, this geographic variation may result from differential effectiveness of the HUD field offices located in each region. Consistent with the FHA market shares reported in Table 1, we see that the Rocky Mountain and Northwest regions have the highest FHA market shares after controlling for area risk factors. It is interesting to note that, although the Great Plains region has one of the lowest FHA market shares, after controlling for area risk factors this region has a significantly higher market share.

16 Ambrose, Pennington-Cross, Yezer 
The institutional market structure variables generally behave as expected. Given that the lenders and mortgage originators reporting their lending activity to HUD are the reference group, the FHA share of FHA-eligible originations should fall as the percentage of loans originated by lenders reporting to other institutions rises. Thus, we see that FHA market shares of FHAeligible originations and applications are lower as the percentage of mortgages originated by institutions that report to the National Credit Union Administration (NCUA), the Federal Deposit Insurance Corporation (FDIC), and the Office of the Comptroller of the Currency (OCC) increases.

\section{SUMMARY AND CONCLUSIONS}

This paper builds on existing literature on the microfoundations of choice between conventional and FHA-insured mortgages. We formulate a model of the effects of location-specific variation in credit risk on FHA market share. Our model allows us to utilize the FHA's policy of ignoring geographic variation in credit risk to explore the nature and effects of credit rationing by conventional lenders.

Based on this theory, and using a combination of HMDA data recently expanded in terms of coverage to include most FHA lenders and data from the FHA system itself, we estimate a series of four simple reduced-form models: FHA share of applications and originations, and FHA and conventional rejection rates. Taken together, these indirect tests strongly suggest that conventional mortgage lending criteria are not relaxed in areas experiencing recession or longer-term decline. Instead, conventional underwriting criteria are either maintained or tightened in the face of local recession, and FHA and conventional shares respond accordingly. Apparently conventional mortgage suppliers reject the possibility of relaxing underwriting criteria and raising mortgage insurance prices to preserve market share in declining areas. For home buyers seeking housing priced at or below the recently increased FHA maximum mortgage amount, FHA insurance is available to maintain mortgage credit supply during recessions or longer declines. For housing priced significantly above the FHA mortgage limit, the effects of non-price rationing of conventional mortgages may be more pronounced. 
We also find that the composition of lenders active in the market and the racial composition of the MSA have an impact on FHA market share. These results should not surprise those familiar with the literature on the role of FHA. Finally, it appears that there is considerable geographic variation in FHA market share remaining to be explained in future research.

\section{REFERENCES}

1. B. W. Ambrose and C. A. Capone, Jr., Modeling the conditional probability of foreclosure in the context of single-family mortgage default resolutions, Real Estate Economics, 26, 391-429 (1998).

2. J. Brueckner, Mortgage default with asymmetric information, Journal of Real Estate Finance and Economics, 20, 251-274 (2000).

3. H. Bunce and R. Scheessele, The GSEs' funding of affordable loans, U.S. Department of Housing and Urban Development Working Paper No. HF-001 (1996).

4. D. Capozza, D. Kazarian, and T. Thomson, Mortgage default in local markets, Real Estate Economics, 25, 631-656 (1997).

5. T. M. Clauretie and T. Herzog, The effect of state foreclosure laws on loan lossesevidence from the mortgage insurance industry, Journal of Money, Credit and Banking 22, 221-233 (1990).

6. Y. Deng and C. Calhoun, A dynamic analysis of adjustable- and fixed-rate mortgage termination,in “ASSA (AREUEA) Annual Meeting," New Orleans (1997).

7. J. V. Duca and S. S. Rosenthal, An empirical test of credit rationing in the mortgage market, Journal of Urban Economics, 29, 218-234 (1991).

8. J. V. Duca and S. S. Rosenthal, Do mortgage rates vary based on household default characteristics? Evidence on rate sorting and credit rationing, Journal of Real Estate Finance and Economics, 8, 99-113 (1994). 
9. M. F. Ferguson and S. R. Peters, What constitutes evidence of lending discrimination? Journal of Finance, 50, 739-748 (1995).

10. S. A. Gabriel and S. S. Rosenthal, Credit rationing, race, and the mortgage market, Journal of Urban Economics, 29, 371-379 (1991).

11. J. L. Goodman, Jr., and J. Nichols, Does FHA increase home ownership or just accelerate it? Journal of Housing Economics, 6, 184-202 (1997).

12. P. H. Hendershott, W. C. LaFayette, and D. R. Haurin, Debt usage and mortgage choice: The FHA-conventional decision, Journal of Urban Economics, 41, 202-217 (1997).

13. P. Linneman and S. Wachter, The impacts of borrowing constraints on homeownership, Real Estate Economics, 17, 389-402 (1989).

14. D. S. Massey and N. A. Denton, The dimensions of residential segregation, Social Forces, 67, 281-315(1988).

15. A. Pennington-Cross and J. Nichols, Credit history and the FHA-conventional choice, Real Estate Economics, 28, 307-336 (2000).

16. J. Sa-Aadu and C. F. Sirmans, Differentiated contracts, heterogeneous borrowers, and the mortgage choice decision, Journal of Money Credit and Banking, 27, 498-510 (1995).

17. W. B. Shear and A. Yezer, An indirect test for differential treatment of borrowers in urban mortgage markets, Real Estate Economics, 10, 405-420 (1983).

18. United States General Accounting Office, Homeownership: Potential effects of reducing FHA's insurance coverage for home mortgages, Report to the Chairman, Subcommittee on Housing and Community Opportunity, Committee on Banking and Financial Services, House of Representatives (1997). 
19. J. C. Weicher, FHA reform: balancing public purpose and financial soundness, Journal of Real Estate Finance and Economics, 5, 133-150 (1992).

20. P. M. Zorn, The impact of mortgage qualification criteria on households' housing decisions: An empirical analysis using microeconomic data. Journal of Housing Research, 3, 51-75 (1993). 


\section{Appendix}

Figure 1

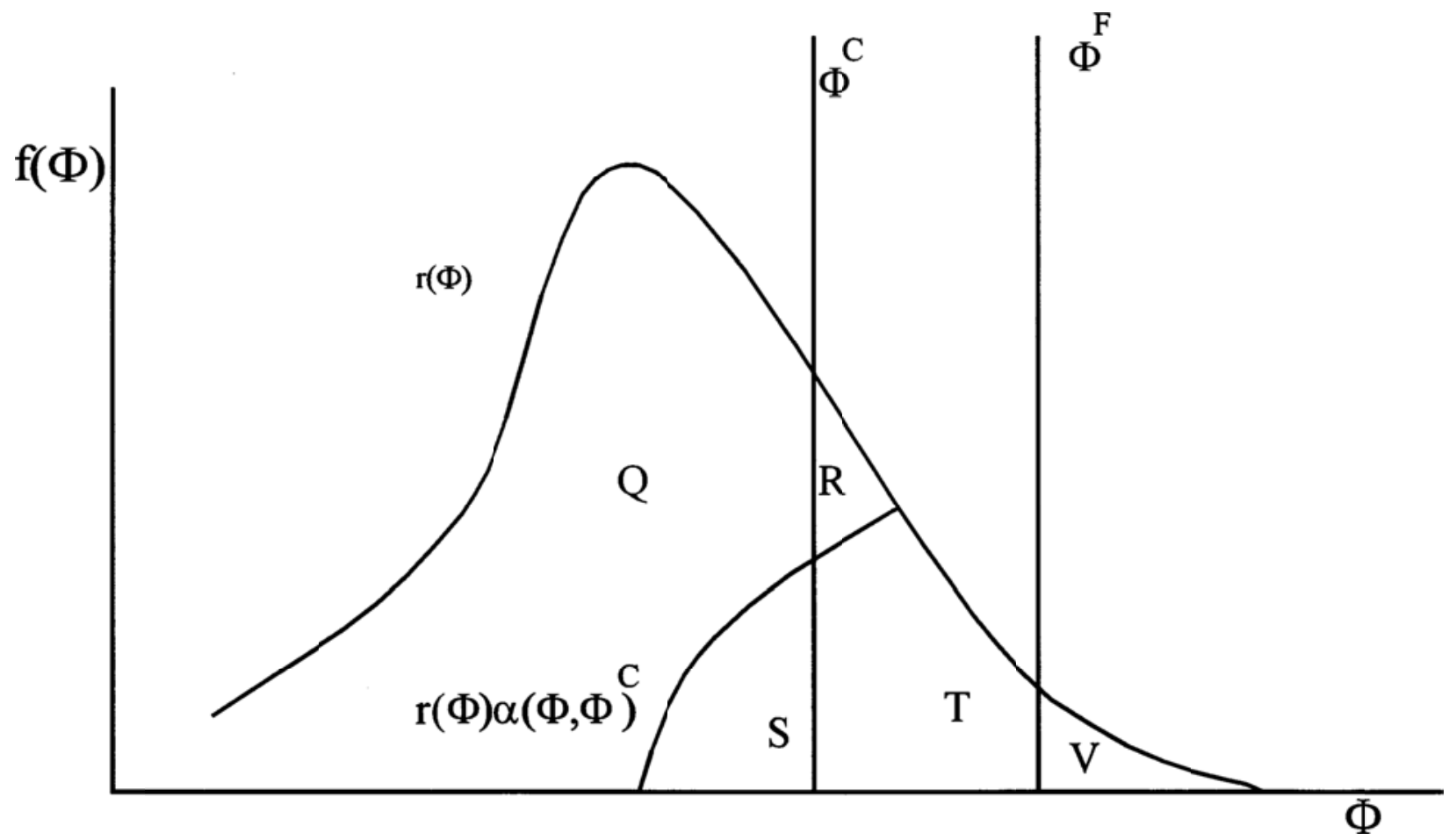

FIG. 1. The FHA wedge. $r(\Phi)=$ marginal probability function of applicant's risk; $\alpha\left(\Phi ; \Phi^{\mathrm{C}}\right)$ share of FHA applicants at a given risk level indexed by $\Phi$ and current conventional lending standards $\left(\Phi^{\mathrm{C}}\right) ; \Phi^{\mathrm{C}}=$ conventional underwriting standard; $\Phi^{\mathrm{F}}=$ FHA underwriting standard; $R=$ conventional rejections; $V=$ FHA rejections; $T=$ FHA wedge; $S+T=$ FHA endorsements; $Q=$ conventional endorsements. 
Figure 2

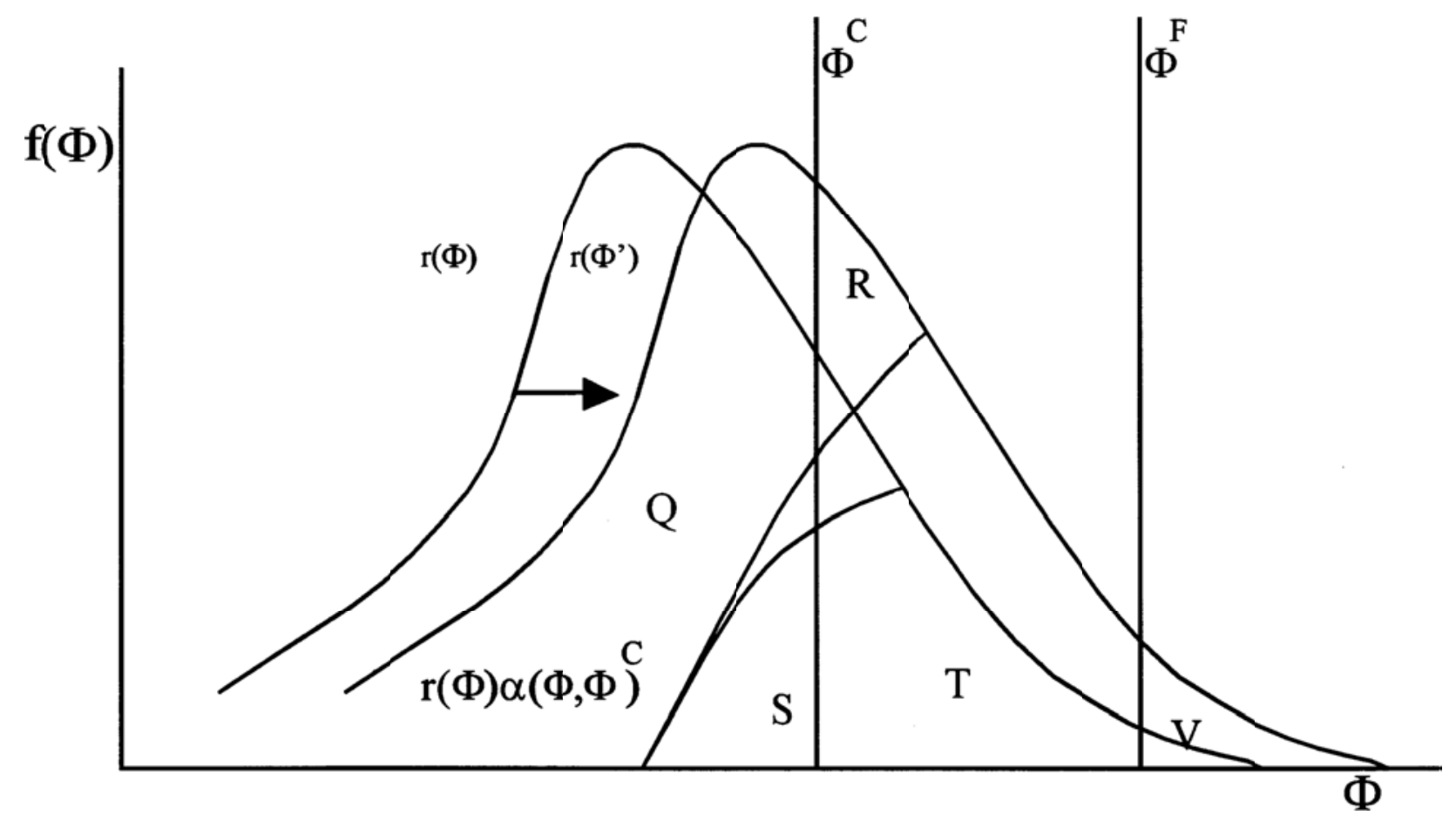

FIG. 2. Maintain conventional lending standards. $r(\Phi)=$ marginal probability function of applicant's risk; $\alpha\left(\Phi ; \Phi^{\mathrm{C}}\right)=$ share of FHA applicants at a given risk level indexed by $\Phi$ and current conventional lending standards $\left(\Phi^{\mathrm{C}}\right) ; \Phi^{\mathrm{C}}$ conventional underwriting standard $\Phi^{\mathrm{F}}=\mathrm{FHA}$ underwriting standard; $R=$ conventional rejections; $V=$ FHA rejections; $T=$ FHA wedge; $S+T=$ FHA endorsements; $Q$ = conventional endorsements. 


\section{Figure 3}

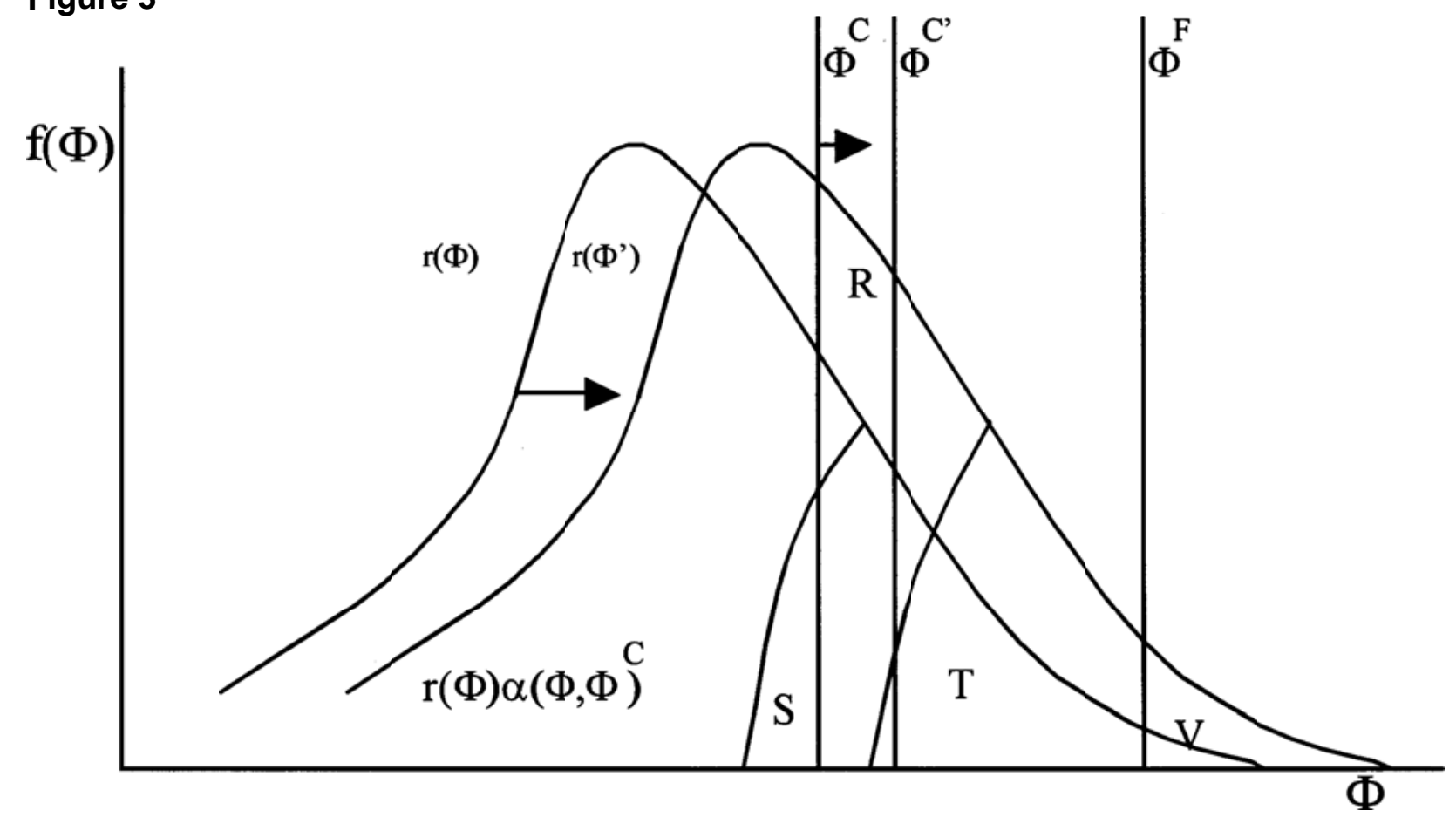

FIG. 3. Loosen conventional lending standards. $r(\Phi)=$ marginal probability function of applicant's risk; $\alpha\left(\Phi ; \Phi^{\mathrm{C}}\right)=$ share of FHA applicants at a given risk level indexed by $\Phi$ and current conventional lending standards $\left(\Phi^{\mathrm{C}}\right) ; \Phi^{\mathrm{C}}=$ conventional underwriting standard; $\Phi^{\mathrm{F}}=$ FHA underwriting standard; $R=$ conventional rejections; $V=$ FHA rejections; $T=$ FHA wedge; $S+T=$ FHA endorsements. 


\section{Table 1}

Effects of an Increase in Local Credit Risk Under Alternative Hypotheses About the Nature of Credit Rationing on Conventional Mortgages: Comparison with Actual Findings

\begin{tabular}{|c|c|c|c|c|}
\hline \multirow[b]{2}{*}{ Outcome } & \multirow[b]{2}{*}{$\begin{array}{l}\text { No change } \\
\text { in standards }\end{array}$} & \multirow[b]{2}{*}{$\begin{array}{l}\text { Relax conven- } \\
\text { tional standards }\end{array}$} & \multicolumn{2}{|c|}{ Empirical findings } \\
\hline & & & $\begin{array}{l}\text { Cyclical } \\
\text { risk }\end{array}$ & $\begin{array}{l}\text { Permanent } \\
\quad \text { risk }\end{array}$ \\
\hline $\begin{array}{l}\text { FHA share } \\
\text { of originations }\end{array}$ & + & - & + & + \\
\hline $\begin{array}{l}\text { FHA share } \\
\text { of applications }\end{array}$ & + & $?$ & + & + \\
\hline $\begin{array}{l}\text { FHA rejection } \\
\text { rate }\end{array}$ & $-/ ?$ & + & $?$ & $-/ ?$ \\
\hline $\begin{array}{l}\text { Conventional } \\
\text { rejection rate }\end{array}$ & + & $?$ & $?$ & + \\
\hline
\end{tabular}

\section{Table 2}

Geographic Variation in FHA Market Share for 1995 and 1996

\begin{tabular}{lccc}
\hline HUD region & $1995(\%)$ & $1996(\%)$ & Total (\%) \\
\hline Midwest & 15.5 & 17.8 & 16.6 \\
& $(9.6)$ & $(10.0)$ & $(10.1)$ \\
Great Plains & 17.6 & 19.5 & 18.1 \\
& $(10.2)$ & $(10.2)$ & $(9.9)$ \\
New England & 19.0 & 22.1 & 19.1 \\
& $(8.3)$ & $(9.0)$ & $(8.5)$ \\
Mid-Atlantic & 20.8 & 22.4 & 20.7 \\
& $(13.6$ & $(14.6)$ & $(13.6)$ \\
Southwest & 26.7 & 28.6 & 27.4 \\
& $(12.1)$ & $(12.6)$ & $(12.4)$ \\
Northwest/Alaska & 21.5 & 26.8 & 23.7 \\
& $(9.2)$ & $(10.5)$ & $(9.4)$ \\
New York/New Jersey & 21.4 & 25.2 & 22.4 \\
& $(10.1)$ & $(9.5)$ & $(9.8)$ \\
Pacific/Hawaii & 29.9 & 27.3 & 28.0 \\
& $(16.9)$ & $(17.2)$ & $(16.9)$ \\
Southeast/Caribbean & 21.8 & 21.1 & 21.6 \\
& $(10.1)$ & $(10.0)$ & $(10.3)$ \\
Rocky Mountains & 35.8 & 35.1 & 37.2 \\
& $(9.2)$ & $(7.9)$ & $(8.9)$ \\
Total & 22.6 & 23.7 & 22.9 \\
& $(12.5)$ & $(12.4)$ & $(12.6)$ \\
\hline
\end{tabular}

The MSA FHA market share of FHA eligible loans is calculated from HMDA. Means and standard deviations are calculated from MSA estimates. Standard deviation is in parentheses. 


\section{Table 3}

Descriptive Statistics for 1995 and 1996

\begin{tabular}{|c|c|c|c|c|c|c|c|}
\hline Description & Source & Variable & Mean & $\begin{array}{l}\text { Std. } \\
\text { Dev. }\end{array}$ & Min & $\operatorname{Max}$ & Obs \\
\hline \multicolumn{8}{|l|}{ Dependent: $Y_{\text {it }}$} \\
\hline $\begin{array}{l}\text { Fraction of FHA- } \\
\text { eligible originations } \\
\text { that FHA makes in } t\end{array}$ & HMDA & FSHR & 0.232 & 0.125 & 0.007 & 0.620 & 614 \\
\hline $\begin{array}{l}\text { Fraction of FHA- } \\
\text { eligible applications } \\
\text { that FHA gets in } t\end{array}$ & HMDA & FSHRA & 0.190 & 0.110 & 0.006 & 0.580 & 614 \\
\hline $\begin{array}{l}\text { Conventional rejection } \\
\text { rate in } t\end{array}$ & HMDA & CREJ & 0.207 & 0.095 & 0.054 & 0.556 & 614 \\
\hline $\begin{array}{l}\text { FHA rejection rate } \\
\text { one in } t\end{array}$ & HMDA & FREJ & 0.114 & 0.059 & 0.000 & 0.529 & 614 \\
\hline \multicolumn{8}{|l|}{ Cyclical: $C_{\text {if }}$} \\
\hline $\begin{array}{l}\text { One-year percent change } \\
\text { in house prices from } \\
t-1 \text { to } t\end{array}$ & $\begin{array}{c}\text { Freddie } \\
\text { Mac }\end{array}$ & $\triangle H P$ & 0.043 & 0.026 & -0.071 & 0.126 & 614 \\
\hline $\begin{array}{l}\text { One-year change in the } \\
\text { unemplcyment rate } \\
\text { from } t-1 \text { to } t\end{array}$ & DRI & $\Delta U$ & -0.003 & 0.007 & -0.035 & 0.058 & 614 \\
\hline $\begin{array}{l}\text { One-year change in the } \\
\text { fraction of consumer } \\
\text { bank loans } 30 \text { days or } \\
\text { more delinquent (state } \\
\text { data) from } t-1 \text { to } 1\end{array}$ & $\mathrm{ABA}$ & $\triangle D E L$ & 0.002 & 0.005 & -0.028 & 0.028 & 614 \\
\hline \multicolumn{8}{|l|}{ Permanent: $P_{\text {it }}$} \\
\hline $\begin{array}{l}\text { Standard deviation of } \\
\triangle H P \text { for previous } \\
10 \text { years in } t\end{array}$ & $\begin{array}{l}\text { Freddie } \\
\text { Mac }\end{array}$ & $\sigma_{\triangle H P}$ & 0.020 & 0.009 & 0.005 & 0.061 & 614 \\
\hline $\begin{array}{l}\text { The 6-year average of } \\
\text { the fraction of mort- } \\
\text { gages } 90 \text { days or } \\
\text { more overdue (state } \\
\text { data) in } t\end{array}$ & MBA & $\overline{D E L}_{t}$ & 0.007 & 0.002 & 0.003 & 0.016 & 614 \\
\hline $\begin{array}{l}\text { Fraction of home buyers } \\
\text { with income less than } \\
\$ 20 \mathrm{k} \text { in } t-1\end{array}$ & HMDA & $I N C<20$ & 0.109 & 0.059 & 0.002 & 0.304 & 614 \\
\hline $\begin{array}{l}\text { Fraction of loans with } \\
\text { Loan Amount/ } \\
\text { Income }>3 \text { in } t\end{array}$ & HMDA & $L T I>3$ & 0.057 & 0.070 & 0.001 & 0.515 & 614 \\
\hline
\end{tabular}




\section{Table 3, continued}

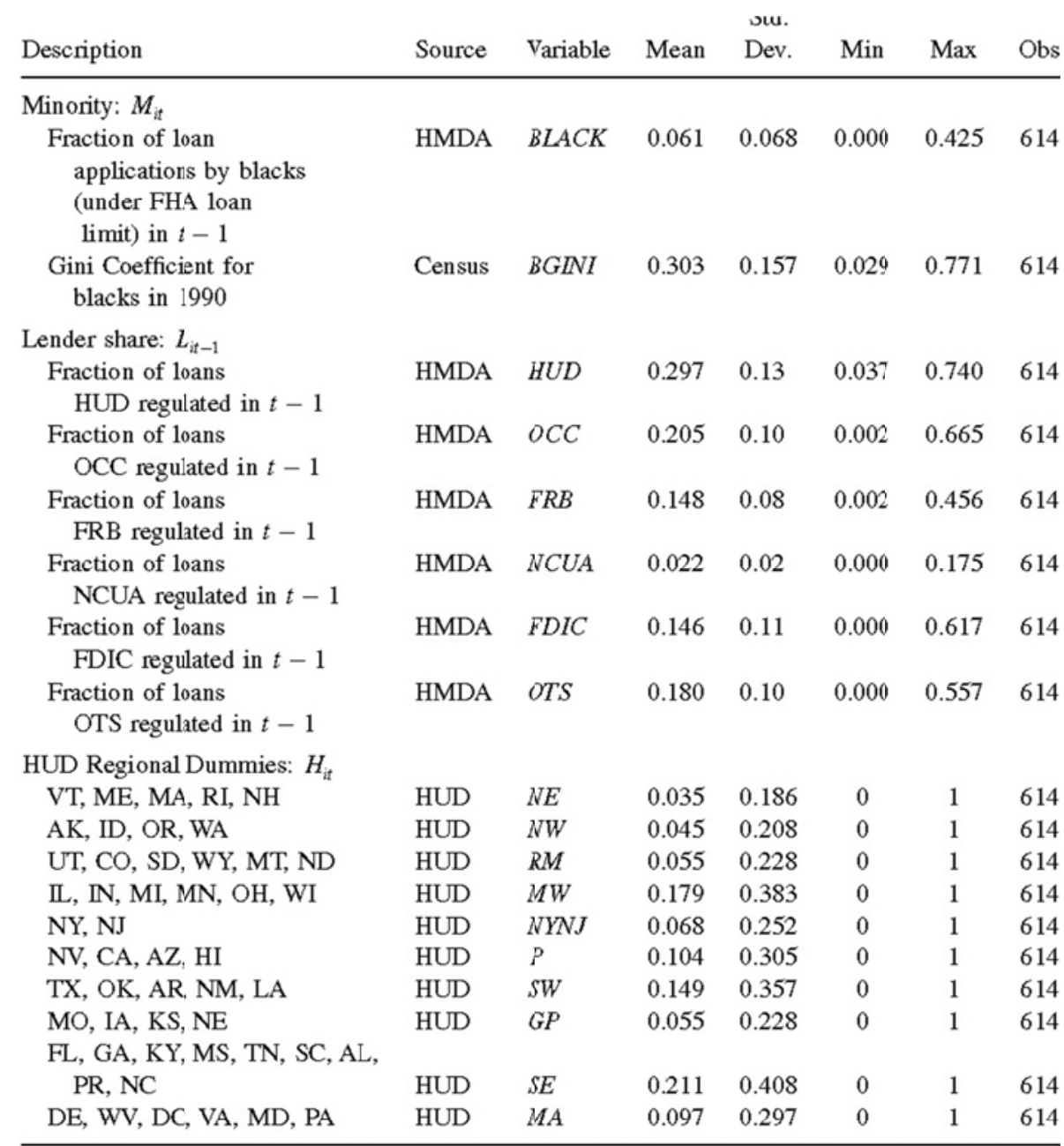

Source abbreviations: DRI, Standard \& Poor's DRI; HUD, Department of Housing and Urban Development: FHA, Federal Housing Authority: BLS; Bureau of Labor Statistics: MBA, Mortgage Bankers Association: ABA, American Bankers Association: HMDA, Home Morgage Disclosure Act: Census, US. Census Bureau: Freddie Mac, Federal Home Loan Mortgage Corporation. 


\section{Table 4}

Model Estimation Results

\begin{tabular}{|c|c|c|c|c|c|c|c|c|c|}
\hline & \multirow[b]{2}{*}{ Variable } & \multicolumn{2}{|c|}{$\begin{array}{l}\text { FHA share of } \\
\text { originations }\end{array}$} & \multicolumn{2}{|c|}{$\begin{array}{l}\text { FHA share of } \\
\text { applications }\end{array}$} & \multicolumn{2}{|c|}{$\begin{array}{c}\text { FHA rejection } \\
\text { rate }\end{array}$} & \multicolumn{2}{|c|}{$\begin{array}{l}\text { Conventional } \\
\text { rejection rate }\end{array}$} \\
\hline & & Coeff. & $T$-stat & oeff. & $T$-stat & Coeff. & $T$-stat & Coeff. & $T$-stat \\
\hline $\begin{array}{l}\text { yclical } \\
\text { risk }\end{array}$ & $\begin{array}{l}\text { Constant } \\
\Delta \mathrm{HP}_{t} \\
\Delta \mathrm{HP}_{t-1} \\
\Delta \mathrm{U}_{t} \\
\Delta \mathrm{DEL}_{t-1}\end{array}$ & $\begin{array}{r}0.19 \\
-2.18 \\
-2.85 \\
1.69 \\
3.02\end{array}$ & $\begin{array}{r}10.4 \\
-36.0 \\
-65.9 \\
8.3 \\
10.3\end{array}$ & $\begin{array}{r}-0.28 \\
-2.11 \\
-2.59 \\
-2.12 \\
6.47\end{array}$ & $\begin{array}{r}-17.7 \\
-40.0 \\
-68.8 \\
-12.3 \\
26.0\end{array}$ & $\begin{array}{r}-2.29 \\
-0.97 \\
1.14 \\
0.76 \\
-1.44\end{array}$ & $\begin{array}{r}-71.2 \\
-6.0 \\
10.0 \\
1.5 \\
-1.8\end{array}$ & $\begin{array}{r}-1.99 \\
1.67 \\
-0.99 \\
5.61 \\
-8.35\end{array}$ & $\begin{array}{r}-154.6 \\
26.6 \\
-21.5 \\
32.5 \\
-33.0\end{array}$ \\
\hline $\begin{array}{l}\text { Permanent } \\
\text { risk }\end{array}$ & $\begin{array}{l}\sigma_{\triangle H P} \\
\overline{D E L} \\
\text { INC }<20_{t-1} \\
\text { LTI }>33_{t-1}\end{array}$ & $\begin{array}{r}7.67 \\
33.38 \\
1.59 \\
-0.50\end{array}$ & $\begin{array}{r}62.6 \\
35.5 \\
38.7 \\
-12.5\end{array}$ & $\begin{array}{l}-0.30 \\
-0.82\end{array}$ & $\begin{array}{r}77.3 \\
35.4 \\
-8.5 \\
-23.2\end{array}$ & $\begin{array}{r}-2.62 \\
0.51 \\
2.86 \\
-0.99\end{array}$ & $\begin{array}{r}-7.9 \\
0.2 \\
28.4 \\
-8.9\end{array}$ & $\begin{array}{r}2.48 \\
19.50 \\
4.42 \\
-0.59\end{array}$ & $\begin{array}{r}19.6 \\
23.4 \\
129.1 \\
-14.5\end{array}$ \\
\hline Minority & $\begin{array}{l}\text { BLACK }_{t-1} \\
\text { BGINI }_{t}\end{array}$ & $\begin{array}{r}2.81 \\
-0.47\end{array}$ & & $\begin{array}{r}2.65 \\
-0.20\end{array}$ & $\begin{array}{r}111.3 \\
-21.5\end{array}$ & $\begin{array}{r}1.01 \\
-0.01\end{array}$ & $\begin{array}{r}14.9 \\
-0.3\end{array}$ & $\begin{array}{r}0.87 \\
-0.72\end{array}$ & $\begin{array}{r}34.8 \\
-68.1\end{array}$ \\
\hline $\begin{array}{l}\text { Lender } \\
\text { share }\end{array}$ & $\begin{array}{l}\text { OCC }_{t-1} \\
\text { FRB }_{t-1} \\
\text { NCUA }_{t-1} \\
\text { FDIC }_{t-1} \\
\text { OTS }_{t-1}\end{array}$ & $\begin{array}{r}-1.18 \\
0.11 \\
-6.45 \\
-3.48 \\
-3.17\end{array}$ & $\begin{array}{r}-57.0 \\
4.4 \\
-66.2 \\
-151.4 \\
-139.5\end{array}$ & $\begin{array}{r}-0.51 \\
0.51 \\
-6.41 \\
-3.17 \\
-2.92\end{array}$ & $\begin{array}{r}-28.7 \\
23.3 \\
-74.4 \\
-156.4 \\
-147.6\end{array}$ & & & & \\
\hline $\begin{array}{l}\text { HUD } \\
\text { regions }\end{array}$ & $\begin{array}{l}\text { NW } \\
\text { RM } \\
\text { MW } \\
\text { NYNJ } \\
\text { P } \\
\text { SW } \\
\text { GP } \\
\text { SE } \\
\text { MA }\end{array}$ & $\begin{array}{r}0.26 \\
0.27 \\
-0.03 \\
-0.79 \\
-0.50 \\
-0.34 \\
0.10 \\
-0.56 \\
-0.17\end{array}$ & $\begin{array}{r}22.7 \\
20.7 \\
-3.0 \\
-80.0 \\
-41.8 \\
-31.4 \\
9.1 \\
-53.6 \\
-16.7\end{array}$ & $\begin{array}{r}0.22 \\
0.28 \\
-0.02 \\
-0.74 \\
-0.40 \\
-0.54 \\
0.11 \\
-0.60 \\
-0.14\end{array}$ & $\begin{array}{r}21.6 \\
24.7 \\
-1.9 \\
-83.4 \\
-38.4 \\
-57.2 \\
11.7 \\
-65.7 \\
-16.1\end{array}$ & $\begin{array}{r}-0.36 \\
-0.56 \\
-0.52 \\
0.01 \\
-0.08 \\
0.09 \\
-0.38 \\
-0.23 \\
-0.48\end{array}$ & $\begin{array}{r}-11.5 \\
-18.8 \\
-22.2 \\
0.5 \\
-3.4 \\
4.0 \\
-14.3 \\
-10.3 \\
-20.6\end{array}$ & $\begin{array}{l}0.56 \\
0.34 \\
0.22 \\
0.16 \\
0.45 \\
1.03 \\
0.43 \\
0.62 \\
0.23\end{array}$ & $\begin{array}{r}49.7 \\
28.7 \\
23.5 \\
16.0 \\
45.3 \\
114.8 \\
40.7 \\
67.4 \\
24.5\end{array}$ \\
\hline $\begin{array}{l}\text { Time } \\
\text { log of likeli }\end{array}$ & $\begin{array}{r}1995 \\
\text { lihood }\end{array}$ & $\begin{array}{r}-0.04 \\
-2,\end{array}$ & -12.7 & $\begin{array}{l}0.06 \\
-2,7\end{array}$ & $\begin{array}{r}18.5 \\
52,247\end{array}$ & $\begin{array}{l}0.01 \\
-35\end{array}$ & $\begin{array}{l}0.5 \\
040\end{array}$ & $\begin{array}{r}-0.31 \\
-2,0\end{array}$ & $\begin{array}{l}-89.2 \\
56,383\end{array}$ \\
\hline & $N$ & 614 & & 614 & & 614 & & 614 & \\
\hline
\end{tabular}

Data are from a cross section of 307 MSAs for 1995 and 1996. A logistic probability model with unscaled weighting was used. 


\section{Table 5}

Marginal Effects for Model Coefficients Reported in Table 4

\begin{tabular}{|c|c|c|c|c|c|}
\hline & & $\begin{array}{c}\text { FHA share of } \\
\text { originations }\end{array}$ & $\begin{array}{c}\text { FHA share of } \\
\text { applications }\end{array}$ & $\begin{array}{c}\text { FHA rejection } \\
\text { rate }\end{array}$ & $\begin{array}{l}\text { Conventional } \\
\text { rejection rate }\end{array}$ \\
\hline & Variable & Coeff. & Coeff. & Coeff. & Coeff. \\
\hline \multirow{5}{*}{$\begin{array}{c}\text { Cyclical } \\
\text { risk }\end{array}$} & Constant & 0.04 & -0.05 & -0.18 & -0.33 \\
\hline & $\Delta \mathrm{HP}_{t}$ & -0.42 & -0.36 & -0.08 & 0.27 \\
\hline & $\Delta \mathrm{HP}_{t-1}$ & -0.55 & -0.44 & 0.09 & -0.16 \\
\hline & $\Delta \mathrm{U}_{t}$ & 0.33 & -0.36 & 0.06 & 0.92 \\
\hline & $\Delta \mathrm{DEL}_{t-1}$ & 0.59 & 1.10 & -0.11 & -1.37 \\
\hline \multirow{4}{*}{$\begin{array}{l}\text { Permanent } \\
\text { risk }\end{array}$} & $\sigma_{\Delta_{H P}}$ & 1.48 & 1.41 & -0.21 & 0.41 \\
\hline & $\overline{D E L}_{t}$ & 6.46 & 4.99 & 0.04 & 3.20 \\
\hline & $\mathrm{INC}<20_{t-1}$ & 0.31 & -0.05 & 0.22 & 0.72 \\
\hline & $\mathrm{LTI}>3_{t-1}$ & -0.10 & -0.14 & -0.08 & -0.10 \\
\hline \multirow[t]{2}{*}{ Minority } & $\mathrm{BLACK}_{t-1}$ & 0.54 & 0.45 & 0.08 & 0.14 \\
\hline & $\mathrm{BGINI}_{t}$ & -0.09 & 0.03 & 0.00 & -0.12 \\
\hline \multirow{5}{*}{$\begin{array}{l}\text { Lender } \\
\text { share }\end{array}$} & $\mathrm{OCC}_{t-1}$ & -0.23 & -0.09 & & \\
\hline & $\mathrm{FRB}_{t-1}$ & 0.02 & 0.09 & & \\
\hline & $\mathrm{NCUA}_{t-1}$ & -1.25 & -1.09 & & \\
\hline & $\mathrm{FDIC}_{t-1}$ & -0.67 & -0.54 & & \\
\hline & OTS $_{t-1}$ & -0.61 & -0.50 & & \\
\hline \multirow{9}{*}{$\begin{array}{l}\text { HUD } \\
\text { regions }\end{array}$} & NW & 0.05 & 0.04 & -0.03 & 0.09 \\
\hline & $\mathrm{RM}$ & 0.05 & 0.05 & -0.04 & 0.06 \\
\hline & MW & -0.01 & 0.00 & -0.04 & 0.04 \\
\hline & NYNJ & -0.15 & -0.13 & 0.00 & 0.03 \\
\hline & $\mathrm{P}$ & -0.10 & -0.07 & -0.01 & 0.07 \\
\hline & SW & -0.06 & -0.09 & 0.01 & 0.17 \\
\hline & GP & 0.02 & 0.02 & -0.03 & 0.07 \\
\hline & SE & -0.11 & -0.10 & -0.02 & 0.10 \\
\hline & MA & -0.03 & -0.02 & -0.04 & 0.04 \\
\hline Time & 1995 & -0.01 & 0.01 & 0.00 & -0.05 \\
\hline
\end{tabular}

Data are from a cross section of 307 MSAs for 1995 and 1996. A logistic probability model with unscaled weighting was used. 
Table 6

Market Share Simulation of HUD-Regulated Institutions for Changes in Cyclical and Permanent Risk

\begin{tabular}{|c|c|c|c|c|}
\hline Region & $\begin{array}{c}\text { FHA share } \\
\text { of originations } \\
(\%)\end{array}$ & $\begin{array}{c}\text { FHA share } \\
\text { of applications } \\
(\%)\end{array}$ & $\begin{array}{c}\text { FHA } \\
\text { rejection rate } \\
(\%)\end{array}$ & $\begin{array}{c}\text { Conventional } \\
\text { rejection rate } \\
(\%)\end{array}$ \\
\hline \multicolumn{5}{|c|}{ A: Baseline market shares } \\
\hline NW & 69.1 & 53.9 & 8.4 & 27.6 \\
\hline $\mathrm{RM}$ & 69.3 & 55.4 & 7.0 & 23.5 \\
\hline MW & 62.6 & 47.9 & 7.3 & 21.4 \\
\hline NYNJ & 43.9 & 30.9 & 11.8 & 20.4 \\
\hline $\mathrm{P}$ & 51.1 & 38.6 & 10.9 & 25.5 \\
\hline SW & 55.1 & 35.4 & 12.6 & 37.9 \\
\hline GP & 65.6 & 51.2 & 8.3 & 25.1 \\
\hline SE & 49.6 & 34.0 & 9.5 & 28.9 \\
\hline MA & 59.2 & 45.0 & 7.5 & 21.5 \\
\hline \multicolumn{5}{|c|}{ B: One standard deviation increase in cyclical risk } \\
\hline NW & 72.3 & 57.4 & 8.4 & 27.2 \\
\hline RM & 72.5 & 58.8 & 7.0 & 23.1 \\
\hline MW & 66.2 & 51.4 & 7.2 & 21.0 \\
\hline NYNJ & 47.8 & 34.0 & 11.7 & 20.1 \\
\hline $\mathrm{P}$ & 55.0 & 42.0 & 10.8 & 25.1 \\
\hline SW & 58.9 & 38.6 & 12.5 & 37.5 \\
\hline GP & 69.0 & 54.7 & 8.2 & 24.7 \\
\hline SE & 53.5 & 37.2 & 9.4 & 28.4 \\
\hline MA & 63.0 & 48.4 & 7.5 & 21.2 \\
\hline \multicolumn{5}{|c|}{ C: One standard deviation increase in permanent risk } \\
\hline NW & 71.9 & 57.2 & 8.3 & 28.9 \\
\hline $\mathrm{RM}$ & 72.1 & 58.7 & 6.9 & 24.6 \\
\hline MW & 65.7 & 51.3 & 7.1 & 22.4 \\
\hline NYNJ & 47.2 & 33.9 & 11.5 & 21.4 \\
\hline $\mathrm{P}$ & 54.5 & 41.8 & 10.6 & 26.7 \\
\hline SW & 58.4 & 38.5 & 12.4 & 39.4 \\
\hline GP & 68.6 & 54.5 & 8.1 & 26.3 \\
\hline SE & 53.0 & 37.1 & 9.3 & 30.1 \\
\hline MA & 62.5 & 48.3 & 7.4 & 22.6 \\
\hline
\end{tabular}

29 Ambrose, Pennington-Cross, Yezer 